\title{
Hogyan jöhetett létre az Iszlám Állam?
}

Bordás Mária: Iszlám kalifátus a 21. században(?) - Az állami hatékonyság kérdései a Közel-Keleten és Afrikában. Budapest: Dialóg Campus, 2015. 336 o. https://oi.org/10.47707/Kulugvi Szemle.2021.1.08

2014-ben a nyugati világ döbbenten figyelte, amint egy transznacio nális, az iszlám szunnita ágához tartozó, de azt extrém módon értelmező terrorista szervezet, az Iszlám Állam (Islamic Sıate, ISIS) egy egész országnyi területet vont az ellenőrzése alá. A nemzetközi közvélemény elszörnyüllködve vette tudomásul, hogy a dollármilliárdokkal támogatott iraki állam és annak a NATO segítségével kiképzett, felfegyverzett hadserege képtelen ellenállni az „Iraki és Levantei Iszlám Állam" rendkívül gyors térnyerésének.

Az ún. „arab tavasz” eseményeit a nyugati államok hatalmas re ményekkel és túlzott elvárásokkal szemlélték, és a vágyaik rózsaszín szemüvegén keresztül nézve értékelték: naivan abban bíztak, hogy egy demokratikus forradalmi hullám söpör végig az arab világon, amelynek eredményeként valódi demokratikus berendezkedésű országok jönnek létre.

A mára területét vesztett és újra földalatti mozgalommá átszerveződött, gerilla taktikát követő, a civil lakosság soraiban megbújó, de még mindig több ezer szélsőséges fegyverest számláló terrorista szervezet továbbra is destabilizáló tényezót jelent a térségben.

Az elmúlt évek egyik legfontosabb világpolitikai eseménye az Iszlám Állam sokak számára váratlan közel-keleti megjelenése volt. Az „arab tavasznak” a térség demokratikus átalakulásával is kecsegtető eseménysorozata után Líbia és Szíria polgárháborúba sodródott, s ott - nem utolsósorban egyes államok politikai, katonai beavatkozása miatt - ma is kaotikus állapotok uralkodnak. A folyamatos belviszályok elterelték a figyelmet az iraki állam gyengeségérỏl, a síitáknak a szunnitákkal szembeni elnyomó politikájáról. Ekkor jelent meg és nyert 
robbanásszerủen teret az Iszlám Állam. A nyugati országokat, mindenekelőtt az Amerikai Egyesült Államokat politikai hidegzuhanyként érte, hogy az általuk dollármilliárdokkal támogatott és demokratikus nak hitt iraki állam és hadsereg kártyavárként omlik össze. Így, termé szetesen, a témában számos tanulmány, cikk és könyv született. Most a valóban könyvtárnyi publikáció közül - a teljesség igénye nélkül csupán néhány küllöldi és magyar munkát hadd említsek meg.

Az egyik legfontosabb ilyen mű Joby Warrick: „Black Flags. The Rise of ISIS" címú, színvonalas könyve, amelyért a szerző 2016-ban Pulitzer-díjat is kapott. Ebben Warrick részletesen feltárja, hogyan vált egy jordániai utcai bűnöző, Abu Muszab az-Zarkávi az al-Káida iraki szervezetének a vezetőjévé, s a később abból kifejlődött ISIS alapítójává. Hasonlóan nívós a 2018-ban Nobel-békedịjjal kitüintetett Nadia Murad: „The Last Girl. My Story of Captivity and My Fight Against the Islamic State" címú, 2017-ben megjelent műve, amelyben a jezidi születésű hölgy a saját szexrabszolgává válását, majd szökését írja le. A könyv 2018-ban „Az utolsó lány. Küzdelmem az Iszlám Állam ellen" címmel magyarul is megjelent.

Muradén kívül más külföldi szerzők művét szintén kiadták magyarul is. Ilyen Hassan Hassan és Michael Weiss: „Az iszlám állam. A terror hadserege belülrôl" címú, 2016-ban megjelent munkája. Azért fontos itt megemlíteni, mert feltárja azt a biztonsági kockázatot és fenyegetést, amelyet az ISIS jelent nemcsak a Közel-Kelet térségére, de az egész civilizált világra. Az arab világ egyik neves ismerője, Rainer Hermann' 2015-ben megjelent: „Az Iszlám Állam. A világi állam kudarca az arab világban" című munkája pedig részletesen bemutatja, hogy az „Iszlám Állam”, amelynek előzményei 1999-ig nyúlnak vissza, a világi államiság kudarca és megszúnése nyomán hogyan tett szert

Dr. Rainer Hermann jelenleg a Frankfurter Allgemeine Zeitung közel-keleti szerkesztője. Közgazdasági szakon végzett (Freiburg Egyetem), PhD-fokozatot pedig Damasz kuszban szerzett, közel-keleti tanulmányok szakon. A FAZ isztambuli tudósítója volt 1991-től 2008-ig, majd 2012-ig az újság abu-dzabi levelezője lett. Több könyvet írt Törökországról és a Közel-Keletről, valamint az Iszlám Államról. Legutóbbi munkája „Arab földrengés. A közel-keleti válság valódi okai” címnel jelent meg. 2018-ban (Frankfurter Allgemeinte Zeitung, é. n.). 


\section{Külïgyi Szemle}

jelentős hatalomra és támogatottságra. A tisztán politikai-történeti elemzésen túlmenően azt is megkockáztatja, hogy egy jól megalapo zott prognózist adjon a távolabbi jövőre vonatkozóan, és tisztázza-ér telmezze a Nyugatnak az eseményekben játszott szerepét.

A magyar szerzők munkái közül Prantner Zoltán: „Iszlám Állam. A vi lág legvéresebb terrorszervezete" címú 2016-os könyvét emelem ki, mi vel az részletes áttekintést ad az ISIS 1999 és 2016 közötti történetéről.

Prof. Dr. Bordás Mária a Nemzeti Közszolgálati Egyetem Államtudo mányi és Közigazgatási Karának méltán elismert egyetemi tanára, aki az „Iszlám kalifátus a 21. században(?) - Az állami hatékonyság kérdései a Közel-Keleten és Afrikában" című munkájában nemcsak az ISIS problémakörét tárgyalja, hanem korunk olyan kérdéseit is feszegeti, illetve igyekszik rájuk válaszokat találni, mint a muzulmán világ és az iszlám radikalizmus kapcsolata - különös tekintettel az utóbbiból táplálkozó terrorizmus terjedésével járó gondokra és veszélyekre.

A kötet a témájában kapcsolódik az Iszlám Állammal foglalkozó művekhez, azonban nagymértékben küilönbözik azoktól. Egyrészt nem egyszerủen az Iszlám Állam kialakulását és történetét taglalja (ahogy teszi azt Hermann, illetve Prantner), és nem is csak a szervezet belső működésére fókuszál (mint Hassan és Weiss), hanem az ISIS-t az állami hatékonyság szempontjából is górcső alá veszi, és elhelyezi a szervezetet az iszlám állami formációk palettáján. Tehát Bordás professzor az államtudomány szempontjai alapján is mélyre ható elemzést végez, és a könyve ezzel teljesen unikális a témát elem ző múvek sorában.

Bordás Mária az ELTE Állam- és Jogtudományi Karán szerzett diplomát 1984-ben, majd ugyanott PhD-fokozatot 1997-ben. 2009ben habilitált a Pécsi Tudományegyetem Állam- és Jogtudományi Karán. Rövidebb idejű tanulmányokat folytatott küllföldön: 1990-ben Strasbourgban (Institute of Comparative Law), 1993-ban Firenzében (Academy of European Law), valamint 1995-ben Salzburgban (Centre for the Study of American Culture and Language). 1999-ben Fulbright vendégprofesszor volt az egyik amerikai egyetemen (Virginia 
Polytechnic Institute and State University), 2013-ban pedig vendégelőadóként európai uniós jogot oktatott az ankarai egyetemen (Middle East Technical University, Faculty of Economic Sciences, Department of International Relations).

2012-2013-ban a Nemzeti Közszolgálati Egyetem Közigazgatás tudományi Karának a tudományos dékánhelyettese, valamint a Közpolitika és Közigazgatás-fejlesztési Tanszék vezetője volt.

2013-ban akadémiai tanácsadóként a török fővárosban dolgozott, a NATO Terrorizmus Elleni Kiválósági Központjában (Centre of Excellence Defence Against Terrorism, COE-DAT). Ottani munkája részeként jelentős kutatásokat végzett a terrorizmus kapesán, többek között az észak-afrikai országokban jelentkező erőszak, az iszlám hagyományok és az állami berendezkedés összefüggései feltárása terén.

Az olvasásra ajánlott könyve hét fejezetre tagozódik, amelyeket a bevezetés és az összegzés foglalja keretbe. Az első fejezetben Bordás professzor az iszlám államok fejlődéstörténetét mutatja be a kalifák korától napjainkig, rámutatva arra, hogy az ismertetett országok milyen sajátos vonásokkal rendelkeznek, és azok milyen módon keverednek a Nyugaton kialakult állami modellek jellemzőivel. Ugyanakkor botorság lenne kizárólag a nyugati értékrend alapján jellemezni és megítélni őket, mivel az iszlám világban nem jöttek létre azok szerint múködő államok, nincsenek a nyugatihoz hasonló osztálytársadalmak, és az iszlámon belül nem ment végbe a keresztény vallásban le zajlott reformációhoz hasonló folyamat. A fejezet második fele a gyar matosítás hatásait és az ún. „szocialista irányultságú” arab országok állammodelljének a válságát tárja fel. A fejezetet, akárcsak a többit, rövid összegzés zárja le, amely következtetéseket is tartalmaz.

A második részben a szerző a palesztin államiság bonyolult kér désének az elemzésére, valamint Izrael és a környező államok szöve vényes, sokszor gyûlölettel telített kapcsolatrendszerének feltárására tesz kísérletet. Nemesak arra a kérdésre keres választ, hogy a „területet békéért" elv miért nem múködik, de bemutatja azt a mélyebb politikai, ideológiai összefüggést is, amely a palesztin ellenállási moz galmakból, szervezetekből a Hamász, a palesztin Iszlám Dzsihád és más, mintegy negyven terrorista szervezet létrejöttéhez vezetett. 


\section{Külïgyi Szemle}

A harmadik fejezet az iszlám fundamentalizmus és a globális ter rorizmus összefüggéseinek a tudományos igényű, de mégis olvasmá nyos elemzése. Bordás professzor mások által soha nem alkalmazott szempontokból, a széles körủ államtudományi ismeretei felhasználásával, az állami berendezkedés szemszögéből veszi górcsô alá az iszlám vallású államokat. Mint megállapítja, kapcsolatot van az ún. szocialista irányultságú államtípusok csődje és a fundamentalizmus elterjedése között, és ezeket az összefüggéseket bizonyitja is. Továbbá összefüiggéseket tár fel az ottani reformációs kísérletek és a radikális iszlámon alapuló terrorizmus elterjedése között. Úgy vélem, tudományos szempontból ez a fejezet a mű egyik legérdekesebb része.

A következô fejezetet a szerző az iszlám fundamentalista államok (Szudán, Irán) és az államszerű képződmények vizsgálatának szenteli. Az olvasó számára talán meglepő ez utóbbi kifejezés, de a két terrorista szervezetnek - a Hamásznak és a Hezbollahnak - sikerült beépüilnie a palesztin, illetve a libanoni államapparátusba, és gyakorlatilag mindegyik „állam az államban”, így nagyon is illik rájuk az „államszerű képződmény" terminológia. A szerző ebben a részben vizs gálja az Iszlám Állam létrejöttének a körüilményeit is, és választ ad arra az egyáltalán nem könnyű kérdésre, hogy az ISIS teljesíti-e az állammal szemben támasztott követelményeket, azaz lehet-e valódi államként kezelni az Iszlám Államot. Ugyanebben a fejezetben olvas ható az ISIS-nek hủségesküt tett nigériai terrorista szervezet, a Boko Haram ismertetése is.

Bordás Mária az ötödik fejezetet az al-Káida elemzésének, vala mint a nyugati irodalomban „arab tavaszként” emlegetett esemény sorozatnak szentelte. Ebben feltárja az al-Káida túlélési lehetősége it azokban az országokban, ahol az „arab tavasz” nem demokratikus eredményeket, hanem káoszt hozott. Tudományos igényességgel tárja fel Líbia és Szíria polgárháborúba süllyedésének az okait - amelyek miatt szinte kilátástalan lett a két ország helyzete.

Ehhez az elemző munkához szervesen kapcsolódik a hatodik fe jezet vizsgálati területe: a problémákkal és ellentmondásokkal terhelt iraki és afganisztáni államépítés, valamint a terrorizmus elleni küzdelem problematikája. A terrorista akciókat elhelyezi az aszimmetrikus 
hadviselési formák hadtudományi kategóriái közé, és különbséget tesz a gerilla harcmodor és a terrorizmus között.

A hetedik fejezetben a professzor asszony már nem államtudo mányi, hanem jogi oldalról készített elemzést, amelyben a terrorizmus elleni fellépés jogi lehetőségeit és korlátait boncolgatja. A fejezet egyik fö üzenete, hogy a törvényalkotás fáziskéséssel tud csak reagálni a terrorista szervezetek által alkalmazott taktikákra.

A professzor az utószóban összegzi a mondanivalóját, de rámutat többek között arra is, hogy a „célzott megsemmisítés” amerikai politikája eddig megkérdőjelezhető eredménnyel járt, és ellentmondásos hatást váltott ki.

A professzor asszony beillesztette az Iszlám Államot a radikális muszlim terrorista szervezetek sorába - mind az ideológiai beállítottság (szunnita fundamentalista, radikális iszlamista), mind a mú ködési szempontok szerint történő kategorizálás alapján. Továbbá megvizsgálta az ISIS-t az állami hatékonyság szempontjai alapján is. Államtudományi szempontú elemzése rámutat arra, hogy az Iszlám Állam igyekszik ugyan állami funkciókat is ellátni (saját pénz, útlevél, bank, oktatás stb.), valójában azonban csupán egy terrorista szervezet, amely - kihasználva az állami gyengeséget - képes volt jelentős területet az ellenőrzése alá vonni.

A könyvet számos kép, térkép és ábra teszi még színesebbé és valóban szemléletessé. A kötet külsőre nem tartozik a legillusztrisabbak közé, ám a tartalma a legigényesebb tudományos kutatót és a téma iránt érdeklődő, laikus olvasót egyaránt kielégíti. A munka választékos, ugyanakkor az ismereteket jól közvetítő, közérthető nyelvezete tovább emeli annak értékét. Mindezek alapján Bordás Mária írását a téma iránt érdeklődőknek és a terrorizmussal foglalkozó tantárgyak oktatóinak is tiszta szívvel ajánlom.

Tomolya János

\section{Irodalomjegyzék}

Frankfurler Allgemeinte Zeilung (é. n.). Rainer Hermann. A letöltés ideje: 2021. február 6. https://www.faz.net/redaktion/rainer-hermann-11123673.html. 